\title{
Adsorption of Fluometuron, Prometryne, Sencor, and 2,4-D by Soils ${ }^{1}$
}

\author{
L. C. Liu and H. R. Cibes-Viadé $\hat{e}^{2}$
}

\section{INTRODUCTION}

Considerable effort has been made in the past 2 decades to study adsorption characteristics of phenoxyacetic acid $(2,4,9,21)$, triazines $(2,3,4,7,-$ $8,9,10,13,14,16,17,19,20,21,22,23)$ and substituted urea herbicides $(2,4, \bar{j}, 6,-$ $7, \$, 9,10,15,24)$. Most of the work reported, however, was conducted under edaphic conditions foreign to our area. Information concerning the adsorption characteristics of the above groups of herbicides by local soils is rather limited. Such information is useful not only for adjusting the rate of herbicide application but also for predicting the relative mobility of various herbicides in our ecosystem. To date, the only published work on this subject relevant to Puerto Rico is that by Liu et al. (12), wherein data was presented concerning the adsorptive capacity of 34 native soils of two of the most commonly used herbicides, namely, 2-chloro-4-(ethylamine)-6-(isopropylamine)-s-triazine (Atrazine), and 3-tert-butyl-5-chloro-6-methyl uracil (Terbacil). The present research is a continuation and expansion of our previous work. This paper reports the adsorption of 1,1-dimethyl-3(trifluro-m-toyl) urea (Fluometuron), 2,4 bis (isopropylamine)-6-(methylthio)-s-triazine (Prometrync), 4-amino-6-tert-butyl-3-(methylthio)-as-triazin-5 $(4 \mathrm{H})$ one (Sencor), and 2,4-dichlorophenoxyacetic acid $(2,4-\mathrm{D})$ by 48 local soils. Prometryne is used commercially to control noxious weeds in coffec (Coffea arabica), plantain (Musa paradisiaca I.), and pigeonpea (Cajamus cajan). 2, 4-D is used widely as a post-emergence herbicide for the control of broad-leaved weeds in various crops of conomic importance in Puerto Rico. Fluometuron and Sencor have shown promising results for weed control in sugarcane (Saccharum officinarum).

\section{MATERIALS AND METHODS}

Samples from the upper layer ( 6 inches) of 48 different soils were collected from various regions of Puerto Rico representing a wide variety of climatic and edaphic conditions. The samples were air-dried, ground and passed through a $0.25-\mathrm{mm}$. screen. The physical and chemical properties of these soils were determined by methods similar to those employed previously (11).

1 . Ianuscript submitted to Editorial Board March 7, 1973.

3 Associate Plant Physiologist and Plant Physiologist, respectively, Agricultural Experiment Station, Mayagüez Campus, University of Puerto Rico, Río Piedras, P.R. 
To determine the extent to which liluometuron, Prometryne, Sencor and 2,4-D were adsorbed by each soil type, the slurry-type procedure outlined by Talbert and Fletchall (16) was followed. Stock solutions (conen. jo p.p.m.) of Fluometuron, Prometryne, and Sencor were prepared with 0.01 $\mathrm{MI} \mathrm{CaCl} 2$ in a $2,000-m l$. volumetric flask. Another stock solution (conen. 35 p.p.m.) of 2,4-D was similarly prepared. Ten ml. of each herbicide were added to individual Erlenmeyer flasks containing $1 \mathrm{~g}$. of soil sample each. The flasks were stoppered and agitated in a reciprocal shaker for 5 hours. Individual samples were then transferred to 15-ml.-capacity glass tubes and centrifuged for 10 minutes at 3,700 r.p.m. Subsequently, $5 \mathrm{ml}$. of the supernatant were removed and placed in a cuvette for spectrophotometric determination. A series of standard eurves were constructed by plotting observed absorbances against known concentrations. The known concentrations used were $0,0.3125,0.625,1.25,2.50$ and 5.00 p.p.m. for Fluometuron, Prometryne, and Sencor. Other known concentrations were used for 2,4-D, namely, $0,2.18 \$, 4.375,8.75,17.50$ and 35.00 p.p.m. The analytical wavelengths used were $240,222,230$ and $283 \mathrm{~m} \mu$ for Fluometuron, Prometryne, Sencor, and 2,4-D, respectively. All the determinations were made in triplicate except when the soil samples were insufficient; in those cases they were made only in duplicate. The difference in herbicide concentration in solution before and after equilibrium with the soil represents the amount of herbicide adsorbed.

\section{RESULIS}

The physical and chemical properties of the 48 soils used in the study are presented in table 1. The adsorption pereentage for liluometuron, Prometryne, Sencor, and 2,4-D are presented in table 2. Data obtained indicated that Prometryne was adsorbed the must, followed by Fluometuron and Sencor with approximately the same percentage, and 2,4-D the least. The adsorption of lrometryne ranged from 7 to 99 percent with a mean of 37.0 percent; that of Sencor from 1 to 61 pereent with a mean of 23.0 percent; that of Fluometuron from 2 to 73 percent with a mean of 22.6 percent; and that of 2,4-D from 0 to 33 percent with a mean of 12.4 percent. The high adsorptive eapacity for these 48 soils, recorded for Prometryne, agrees with the results obtained by Talbert and Fletchall (16) and Harris (7). The high levels of adsorption by the soils could be attributed to the protonatedmolecular configuration of the herbicide as suggested by Weber et al. (20). This same mechanism does not seem to operate in the case of Sencor, another triazine herbicide. The low to moderate adsorption of nonionic Fluometuron by soils has also been reported by Abernathy and Davidson (1). The adsorption of nonionic phenylurea herbicides, including Fluometuron, is probably the result of a dipole-ion or dipole-dipole bonding mechanism (18). The low adsorption of 2,4-D by the tested soils as re- 


\begin{tabular}{|c|c|c|c|c|c|c|c|c|c|c|}
\hline \multirow[b]{2}{*}{ Soil type } & \multirow[b]{2}{*}{$\begin{array}{c}\mathbf{P} \\
\text { p.p.m. }\end{array}$} & \multirow[b]{2}{*}{$\mathrm{pH}$} & \multicolumn{4}{|c|}{ Meq. per $100 \mathrm{~g}$. } & \multicolumn{4}{|c|}{ Percent } \\
\hline & & & CEC & $\mathrm{Ca}$ & $\mathbf{M g}$ & $\mathbf{K}$ & $\begin{array}{c}\text { Or- } \\
\text { ganic } \\
\text { matter }\end{array}$ & Sand & Silt & Clay \\
\hline Aguadilla loamy sand & 17 & 7.4 & 10.0 & 17.1 & 3.3 & 0.20 & 2.5 & 74.4 & 19.5 & 6.1 \\
\hline Aguirre clay loam & 22 & 9.0 & 14.3 & 18.3 & 28.8 & 1.44 & 1.3 & 27.6 & 35.6 & 36.8 \\
\hline Aguirre clay & 32 & 8.4 & 59.0 & 39.0 & 37.5 & .58 & 3.9 & 16.6 & 13.0 & 70.4 \\
\hline Alonso clay & 4 & 5.1 & 13.8 & 5.4 & 2.0 & .91 & 3.2 & 14.9 & 39.3 & 45.8 \\
\hline Altura loam & 33 & 8.0 & 27.6 & 32.2 & 7.8 & 1.94 & 3.7 & 49.2 & 28.8 & 22.0 \\
\hline Bayamón sandy clay loam & 6 & 4.7 & 5.0 & 2.7 & 1.5 & .19 & 1.7 & 68.1 & 4.4 & 27.0 \\
\hline Cabo Rojo sandy clay & 1 & 4.3 & 9.0 & 1.0 & .5 & .10 & 3.1 & 56.4 & 8.0 & 35.9 \\
\hline Caño Tiburones muck & 6 & 5.5 & 86.0 & (i1.9) & 14.0 & .80 & 36.0 & 36.0 & 36.0 & 28.0 \\
\hline Catalina clay & 1 & 4.7 & 11.8 & 0.7 & .6 & .08 & 1.9 & 6.6 & 28.9 & 64.5 \\
\hline Cartagena clay loam & 53 & 7.7 & 36.1 & 25.6 & 19.2 & .69 & 1.7 & 47.2 & 17.4 & 35.4 \\
\hline Cataño sand & 14 & 7.9 & 6.9 & - & .2 & .15 & 2.1 & 89.0 & 7.3 & 3.7 \\
\hline Cintrona clay loam & 31 & 8.3 & 25.0 & 29.9 & 13.5 & 1.35 & 2.5 & 43.4 & 25.2 & 31.4 \\
\hline Cayaguá sandy loam & 4 & 5.2 & 7.3 & 32.2 & 7.8 & 1.94 & 2.0 & 58.8 & 23.4 & 17.8 \\
\hline Cialitos clay & 5 & 5.4 & 18.6 & 6.9 & 7.0 & .54 & 4.9 & 13.3 & 34.8 & 51.9 \\
\hline Coloso clay & 8 & 5.7 & 23.0 & 14.9 & 5.8 & .15 & 3.7 & 22.7 & 37.4 & 39.9 \\
\hline Corozal clay & $\mathbf{0}$ & 4.6 & 17.0 & 6.1 & .9 & .52 & 4.3 & 26.0 & 18.6 & 55.4 \\
\hline Coto clay & 13 & 7.7 & 14.0 & 16.6 & .7 & .35 & 3.2 & 23.4 & 24.8 & 51.8 \\
\hline Estación clay loam & 14 & 5.9 & 10.0 & 6.7 & 5.4 & .08 & .9 & 48.0 & 20.6 & 31.4 \\
\hline Fe clay loam & 13 & 7.5 & 27.6 & 8.7 & 20.8 & .81 & 3.4 & 39.1 & 29.7 & 32.2 \\
\hline Fortuna silty clay loam & 5 & 5.4 & 23.3 & 9.2 & 10.1 & .15 & 3.3 & 15.0 & 50.7 & 34.3 \\
\hline Fraternidad clay & 15 & 6.3 & 36.0 & 24.0 & 10.4 & .46 & 2.1 & 15.5 & 32.5 & 52.0 \\
\hline Fraternidad clay (Lajas) & 33 & 5.9 & 58.0 & 27.6 & 19.0 & .65 & 4.2 & 11.1 & 23.8 & 65.1 \\
\hline Guánica clay & 36 & 8.1 & 52.1 & +1.5 & 37.7 & 2.58 & 4.8 & 0.4 & 19.6 & 74.0 \\
\hline Humacao sand & 9 & 6.3 & 4.0 & 3.7 & .7 & .15 & 1.1 & 84.4 & 8.4 & 7.2 \\
\hline Humata silty clay loam & 4 & 4.5 & 10.1 & 2.2 & .9 & .27 & 1.7 & 10.1 & 50.9 & 39.0 \\
\hline Josefa silty loam & 5 & 6.0 & 16.8 & 7.4 & 9.5 & .22 & 3.3 & 20.6 & 53.5 & 20.9 \\
\hline Juncos silty clay & 9 & 6.2 & 13.4 & 16.6 & 28.8 & .17 & 2.7 & 15.2 & 41.6 & 43.2 \\
\hline Mabí clay & 16 & 7.0 & 55.2 & 19.1 & 43.7 & .50 & 3.9 & 19.9 & 33.4 & 46.7 \\
\hline Mabí clay loam & 3 & 5.7 & 31.0 & 11.5 & 14.2 & .56 & 4.9 & 22.7 & 40.7 & 36.6 \\
\hline Machete sandy loam & 8 & 6.5 & 8.0 & 5.2 & 4.1 & .19 & 2.2 & 76.0 & 13.4 & 10.6 \\
\hline Mercedita silty clay & 25 & 8.1 & 19.9 & 49.9 & 9.9 & 1.02 & 2.4 & 14.9 & +2.8 & 42.3 \\
\hline Moca clay & 6 & 5.8 & 31.0 & 23.4 & 4.7 & .22 & 3.8 & 20.3 & 27.7 & 40.0 \\
\hline Múcara loam & 6 & 5.8 & 19.6 & 13.6 & 7.8 & .14 & 3.3 & 28.0 & 47.0 & 25.0 \\
\hline Nipe clay loam & 2 & 5.7 & 11.9 & 4.4 & 2.5 & .05 & 5.3 & 22.0 & 49.2 & 28.0 \\
\hline Pandura sandy loam & 5 & 5.7 & 7.7 & 5.5 & 2.4 & .13 & 2.0 & 59.4 & 28.2 & 12.4 \\
\hline Río Piedras silty clay & 4 & 4.9 & 11.5 & 3.9 & 2.0 & 08 & 3.5 & 13.4 & 43.6 & 43.0 \\
\hline Sabana Seca clay & 23 & 7.4 & 23.0 & 23.4 & 6.5 & .18 & 3.9 & 39.0 & 24.6 & 36.4 \\
\hline San Antón clay loam & 22 & 7.4 & 28.0 & 11.7 & 1.9 & 1.20 & 4.9 & 47.0 & 24.4 & 28.6 \\
\hline Santa Isabel loam & 42 & 7.4 & 28.0 & 16.2 & 11.9 & 1.11 & 2.1 & 57.0 & 18.6 & 24.4 \\
\hline Soller clay loam & 18 & 6.9 & 53.0 & $4(j .1$ & 5.7 & .37 & 10.4 & 46.0 & 20.0 & 34.0 \\
\hline Talante sandy loam & 7 & 5.1 & 4.0 & .9 & .2 & .17 & 1.4 & 73.4 & 19.4 & 7.2 \\
\hline Toa clay & 33 & 8.0 & 36.0 & 43.7 & .8 & .29 & 5.1 & 35.0 & 24.6 & 40.4 \\
\hline Toa loam & 2 & 5.3 & 13.0 & 6.9 & 1.5 & .23 & 2.0 & 41.5 & 38.3 & 20.2 \\
\hline Toa sandy loam & 8 & 6.0 & 8.0 & 6.2 & 1.4 & .17 & .6 & 60.9 & 25.1 & 14.0 \\
\hline Vega Alta sandy loam & 2 & 5.0 & 5.6 & 1.1 & 1.3 & .02 & 3.5 & 73.7 & 12.6 & 13.7 \\
\hline Via loam & 3 & 5.1 & 39.9 & 3.9 & 3.5 & .10 & 2.3 & 45.2 & 36.8 & 18.0 \\
\hline Vivi loam & 3 & 4.8 & 14.0 & 4.0 & 2.5 & .12 & 2.2 & 62.4 & 19.6 & 18.0 \\
\hline Voladura clay & 1 & 4.3 & 17.7 & .5 & .5 & .21 & 4.5 & 15.0 & 23.4 & 61.6 \\
\hline
\end{tabular}


Taвze: 2.-Adsorption (percenlage) of Fluomeluron, Prometryne, Sencor, and 2,4-D by 48 local soils

\begin{tabular}{|c|c|c|c|c|}
\hline \multirow{2}{*}{ Soil type } & \multicolumn{4}{|c|}{ Adsorption percentage } \\
\hline & Fluometuron & Prometryne & Sencor & $2,4-D$ \\
\hline Aguadilla loamy sand & 12 & 28 & 20 & 4 \\
\hline Aguirre clay loam & 15 & 17 & 27 & 17 \\
\hline Aguirre clay & 50 & 30 & 21 & 10 \\
\hline Alonso clay & 21 & 42 & 24 & 13 \\
\hline Altura loam & 16 & 27 & 8 & $\mathbf{5}$ \\
\hline Bayamón sandy clay loam & 10 & 25 & 12 & 8 \\
\hline Cabo Rojo sandy clay & 10 & 50 & 35 & 18 \\
\hline Caño Tiburones muck & 73 & 99 & 59 & 33 \\
\hline Catalina clay & 28 & 37 & 46 & 12 \\
\hline Cartagena clay loam & 19 & 22 & 25 & 7 \\
\hline Cataño sand & 25 & 7 & 8 & 4 \\
\hline Cintrona clay loam & 28 & 34 & 24 & 22 \\
\hline Cayaguá sandy loam & 9 & 28 & 9 & 11 \\
\hline Cialitos clay & 27 & 40 & 22 & -1 \\
\hline Coloso clay & 30 & 45 & 10 & 23 \\
\hline Corozal clay & 22 & 45 & 29 & 15 \\
\hline Coto clay & 22 & 28 & 25 & 13 \\
\hline Estación clay loam & 14 & 23 & 12 & 8 \\
\hline Fe clay loam & 33 & 49 & 23 & 6 \\
\hline Fortuna silty clay loam & 17 & 61 & 20 & 6 \\
\hline Fraternidad clay & 16 & 25 & 15 & 7 \\
\hline Fraternidad clay (Lajas) & 20 & 35 & 28 & 17 \\
\hline Guánica clay & 30 & 34 & 30 & 9 \\
\hline Humacao sand & 13 & 28 & 12 & 10 \\
\hline Humata silty clay loam & 19 & 48 & 14 & 5 \\
\hline Josefa silty loam & 13 & $4 \bar{\imath}$ & 12 & 6 \\
\hline Juncos silty clay & 31 & 29 & 18 & 5 \\
\hline Mabi clay & 16 & 17 & 32 & 7 \\
\hline Mabi clay loam & 35 & 39 & 61 & 9 \\
\hline Machete sandy loam & 21 & 32 & 24 & 12 \\
\hline Mercedita silty clay & 10 & 28 & 35 & 11 \\
\hline Moca clay & $2 !$ & 51 & 29 & 8 \\
\hline Múcara loam & 8 & 46 & 5 & -1 \\
\hline Nipe clay loam & 25 & 55 & 23 & 24 \\
\hline Pandura sandy loam & 19 & 7 & 11 & 4 \\
\hline Rio Piedras silty clay & 8 & 45 & 26 & 19 \\
\hline Sabana Seca clay & 22 & 23 & 25 & 12 \\
\hline San Antón clay loam & 27 & 21 & 40 & 28 \\
\hline Santa Isabel loam & 29 & 47 & 26 & 5 \\
\hline Soller clay loam & 41 & 97 & 32 & 16 \\
\hline Talante sandy loam & 12 & 22 & 23 & 14 \\
\hline Toa clay & 40 & 57 & 44 & 13 \\
\hline Toa loam & 16 & 35 & 6 & 7 \\
\hline Toa sandy loam & 2 & 12 & 1 & 5 \\
\hline Vega Alta sandy loam & 31 & 29 & 22 & 5 \\
\hline Vía loam & 10 & 32 & 6 & 13 \\
\hline Viví loam & 20 & 36 & 17 & 20 \\
\hline Voladura clay & 37 & 61 & 22 & 44 \\
\hline Mean & 22.6 & 37.0 & 23.0 & 12.4 \\
\hline
\end{tabular}

1 No value; negative adsorption. 
vealed by this study, indicates the great potential of this herbicide to leach or move away from the site of its application. This low adsorption could be attributed to the fact that negatively charged soil colloids tend to repel the negatively charged anionic 2,4-D predominating in the neutral aqueous system (18).

Correlation studies of the soil properties and herbicide adsorption percentages indicated that organic matter was the soil component most highly correlated with adsorption of liluometuron, Prometryne, Sencor, and 2,4-D (table 3). The following regression equations were obtained from the rela-

TABLE 3.-Influence of cerlain soil properties on adsorplion percenlage for the herbicides Fluomeluron, Prometryne, Sencor and 2,4-D, using 48 soil types

\begin{tabular}{l|c|c|c|c|c|c|c|c|c|c}
\hline Factors correlated & $\mathrm{P}$ & $\mathrm{pH}$ & $\mathrm{CEC}$ & $\mathrm{Ca}$ & $\mathrm{Mg}$ & $\mathrm{K}$ & $\begin{array}{l}\text { Organic } \\
\text { matter }\end{array}$ & $\mathrm{Sand}$ & $\mathrm{Silt}$ & $\mathrm{Clay}$ \\
\hline $\begin{array}{c}\text { Adsorption per- } \\
\text { centage for Fluo- }\end{array}$ & 0.13 & 0.14 & $0.63^{* *}$ & $0.48^{* *}$ & 0.24 & 0.09 & $0.72 * *$ & -0.20 & -0.07 & $0.32^{*}$ \\
$\begin{array}{c}\text { meturon } \\
\text { Adsorption per- } \\
\text { centage for Pro- } \\
\text { metryne }\end{array}$ & -.17 & -.25 & $.43^{* *}$ & $.31^{*}$ & -.10 & -.07 & $.66^{* *}$ & $-.30^{*}$ & .26 & .20 \\
$\begin{array}{c}\text { Adsorption per- } \\
\text { centage for Sen- } \\
\text { cor }\end{array}$ & .12 & .09 & $.46^{* *}$ & $.37^{*}$ & .18 & .14 & $.52^{* *}$ & $-.31^{*}$ & .02 & $.39^{* *}$ \\
$\begin{array}{c}\text { Adsorption per- } \\
\text { centage for 2,4-D }\end{array}$ & -.14 & -.20 & .22 & .08 & -.14 & .02 & $.45^{* *}$ & -.21 & .03 & .24 \\
\hline
\end{tabular}

* Significant at 5-percent level.

** Significant at 1-percent level.

tion between the organic matter content of the soil and the percentage of herbicide adsorption: $Y=1.78 .3 \mathrm{X}+15.833$ for Fluometuron; $Y=$ 2.425X +27.712 for Prometryne; $Y=1.337 X+17.890$ for Sencor; and $Y=0.737 \mathrm{X}+9.585$ for $2,4-\mathrm{D}$ (fig. 1 ). Using the above mentioned relationships, the unknown percentage of adsorption of each of the four herbicides by a given soil can be predicted through the known amount of organic matter present in the soil. Cation exchange capacity was found to be the next in importance with respect to adsorption of Fluometuron, Prometryne, and Sencor by the soils. However, such was not the case with 2,4-D. Correlation between clay content and adsorption of Fluometuron and Sencor was statistically significant. In contrast, no significant correlation was noted between clay content and adsorption of Prometryne and $2,4-\mathrm{D}$. 
ADSORPTION OF FOUR HERBICIDES BY 48 PUERTO RICAN SOILS 291

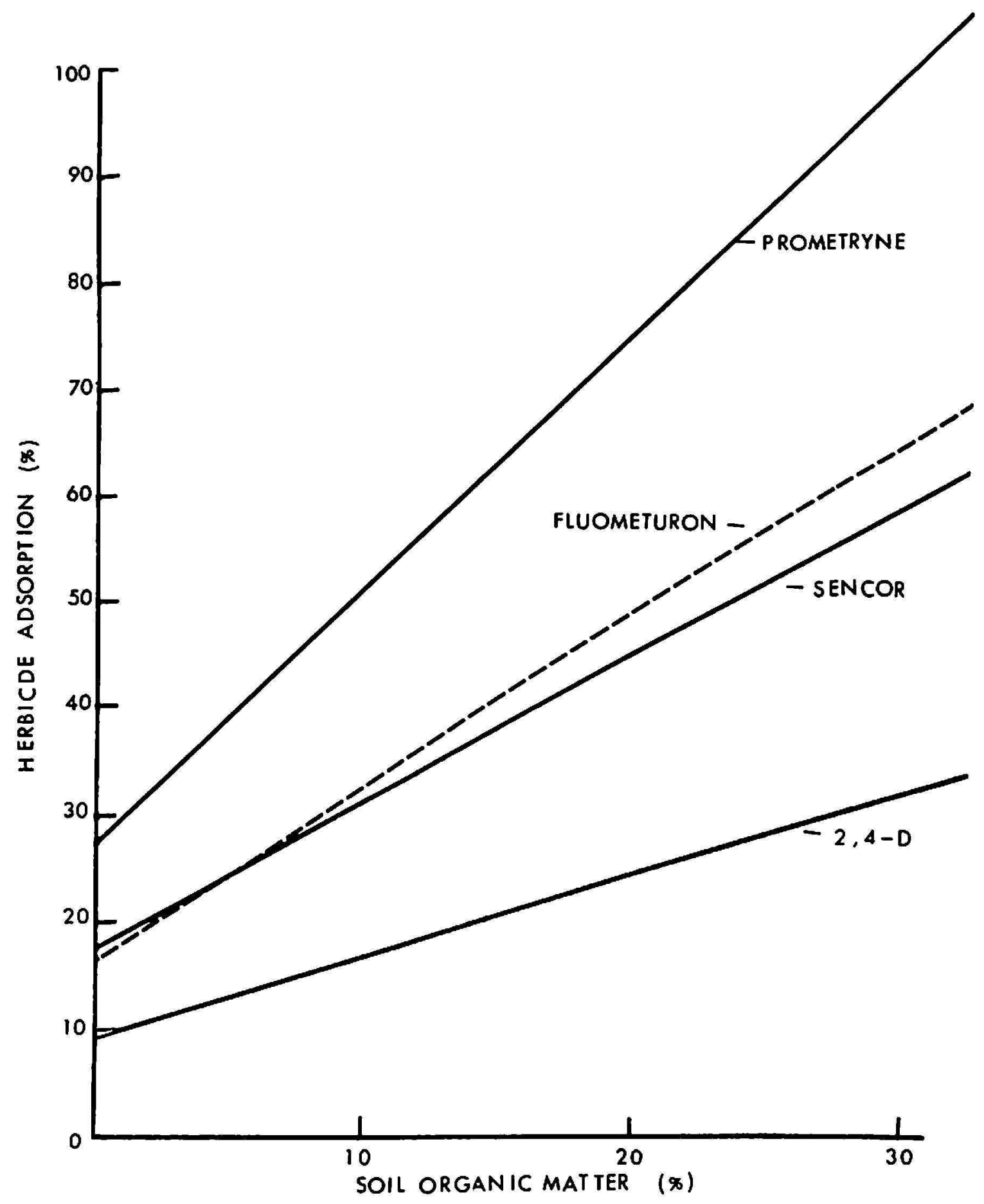

Fig. 1.-Theoretical relationship between soil organic matter content and herbicide adsorption of Fluometuron, Prometryne, Sencor, and 2,4-D for 48 soils of Puerto Rico.

\section{SUMMARY}

The adsorption capacity of Fluometuron, Prometryne, Sencor, and 2,4-D by 48 local soils was determined spectrophotometrically. The mean adsorptivities of the four herbicides by these soils were as follows: Prome- 
tryne 37.0 percent, Sencor 23.0 percent, Fluometuron 22.6 percent, and 2,4-D 12.4 percent. The results indicated that organic matter content was the factor most highly correlated with adsorption of these herbicides by the 48 soils. Cation exchange capacity was found to correlate significantly with adsorption of Fluometuron, Prometryne, and Sencor. Such was not the case with 2,4-D. Correlation between clay content and adsorption of Fluometuron and Sencor was statistically significant. In contrast, no significant correlation was noted between clay content and adsorption of Prometryne and 2,4-D.

\section{RESUMEN}

Se estudió en el laboratorio, usando métodos espectrofotométricos, la capacidad relativa de 48 tipos de suelos de Puerto Rico para adsorber los yerbicidas Fluometuron, Prometryne, Sencor y 2,4-1). Las capacidades promedio de los suelos para adsorber estos cuatro yerbicidas fueron las siguientes: Prometryne 37.0 por ciento, Sencor 23.0 por ciento, Fluometuron 22.6 por ciento y 2,4-D 12.4 por ciento. Los resultados indicaron que el contenido de materia orgánica fue el factor más altamente correlacionado con la capacidad de estos 48 suelos para adsorber los antedichos yerbicidas. Se demostró que existe una correlación positiva entre el intercambio de cationes y la adsorción de Fluometuron, Prometryne y Sencor por los suelos. Sin embargo, no fue así en el caso del 2,4-I). Se determinó que la correlación entre el contenido de arcilla y la adsorción de Fluometuron y Sencor fue estadísticamente significativa. Por contraste, no se notó una correlación significativa entre el contenido de arcilla y la adsorción de Prometryne y 2,4-1).

\section{LITERATURE CITED}

1. Abernathy, J. R., and Davidson, J. M., Effect of calcium chloride on Prometryne and Fluometuron adsorption in soil, Weed Sci. 19: 517-21, 1971.

2. Bailey, G. W., and Rothberg, T., Adsorption of organic herbicides by montmorillonite. Role of $\mathrm{pH}$ and chemical character by adsorbate, Soil Sci. Soc. Amer. Proc. 32: 222-34, 1968.

3. Day, B. E., Jordan, L. S., and Jollife, V. A., The influence of soil characteristics on the adsorption and phytotoxicity of Simazine, Weed Sci. 16: 209-13, 1968.

4. Frissel, M. J., and Bolt, C. H., Interaction between certain ionizable organic compounds (herbicides) and clay minerals, Soil Sci. 94: 284-91, 1962.

5. Hance, R. J., Observations on the relationship between the adsorption of Diuron and the nature of the adsorbent, Weed Res. 5: 108-14, 1965.

6. - The adsorption of urea and some of its derivatives by a variety of soils, Weed Res. 5: $98-107,1965$.

7. Harris, C. I., Adsorption, movement and phytotoxicity of Monuron and s-triazine herbicides in soil, Weeds $14: 4-10,1966$.

8.- and Sheets, T. J., Influence of soil properties on the adsorption and phytotoxicity of CIPC, Diuron and simazine, Weeds $13: 215-9,1965$.

9. - , and Warren, G. F., Adsorption and desorption of herbicides by soil, Weeds 12: 120-6, 1964.

10. Hilton, H. W., and Yuen, Q. H., Adsorption and leaching of herbicides in Hawaiian soils, J. Agr. \& Food Chem. 14: 86-90, 1966 .

11. Liı, L. C., and Cibes-Viadé, H. R., Influence of soil properties on the phytotoxic- 
ity of Atrazine, Ametryne, Prometryne and Diuron in Puerto Rican soils, J. Agr. Univ. P.R. 52 (4): 269-80, 1968.

12. -, 一, and Koo, F. K. S., Adsorption of Atrazine and Terbacil by soils, J. Agr. Univ. P.R. 55 (4): 451-60, 1971.

13. McGlamery, M. D., and Slife, F. W., The adsorption and desorption of Atrazine as affected by $\mathrm{pH}$, temperature, and concentration, Weeds $14: 237-9,1966$.

14. Nearpass, D. C., Effect of soil acidity on adsorption, penetration and persistence of Simazine, Weeds 13: 341-6, 1965.

15. Sherburne, H. R., and Freed, V. M., Adsorption of 3-(p-chlorophenyl)-1,1-dimethylurea as a function of soil constituents, J. Agr. \& Food Chem. 2: 937-9, 1954.

16. Talbert, R. E., and Fletchall, $\mathrm{O}$. H., The adsorption of some s-triazine herbicide in soils, Weeds 13: 46-52, 1965.

17. -, Smith, D. R., and Frans, R. li., Volntilization, leaching and adsorption of Prometryne in relation to selectivity in cotton, Weed Sci. 19: 6-10, 1971.

18. Weber, J. B., Interaction of organic pesticides with particulate matter in aquatic and soil system, Advances in Chemistry Series 111: 99-105, 1972.

19. -, Molecular structure and $\mathrm{pH}$ effect on the adsorption of 13 s-triazine compounds on Montmorillonite clay, The $\Lambda$ merican Mineralogist 51: 1,657-70, 1966.

20. -, Perry, P. W., and Ibaraki, K., Effect of $\mathrm{pH}$ on the phytotoxicity of Prometryne applied to synthetic soil media, Weed Sci. 16: 134-6, 1968.

21. -, and Upchurch, R. P., The influence of temperature and time on adsorption of Paraquat, Diquat, 2,4-D and Prometone by clays, charcoal and an anion-exchange resin, Soil Sci. Soc. Amer. Proc. 29: 678-88, 1965.

22. - , and Weed, S. B., Adsorption and desorption of Diquat, Paraquat and Prometone by montmorillonite and kaolinitic clay mineral, Soil Sci. Soc. Amer. Proc. 32: $584,1968$.

23. -, and Ward, T. M., Adsorption of s-triazines on soil organic matter, Weed Sci. 417-21, 1969.

24. Yuen, Q. H., and Hilton, H. W., Soil adsorption of herbicides: The adsorption of Monuron and Diuron by Hawaiian sugarcane soils, J. Agr. \& Food Chem. 00: $386-92,1962$. 